\title{
STUDY ON AGROFORESTRY PRACTICES IN ABAK LOCAL GOVERNMENT AREA, AKWA IBOM STATE, NIGERIA
}

\author{
S. I. UDOFIA, P. W. OWOH AND Y. K. THOMAS \\ (Received 18, February 2008; Revision Accepted 14, January 2010)
}

\begin{abstract}
A study was carried out to assess the various agroforestry practices in Abak Local Government Area (LGA) of Akwa Ibom State, Nigeria. Structured questionnaires, physical observations and oral interview were used to collect data from agroforestry farmers (respondents) in the four clans (Abak, Otoro, Midim and Afaha-Obong) in Abak Local Government Area of Akwa lbom State, Nigeria. Results showed that $67.25 \%$ of the respondents were males whereas $32.75 \%$ were females. $81.75 \%$ of the respondents were in the age brackets of $30-49$ years, while those in age brackets 50 years and above were $18.25 \%$. Married people constituted $89.50 \%$ of the respondents with $0.50 \%$ as single; $56.75 \%$ engaged in fulltime farming, $20 \%$ were civil servants/farmers and $23.25 \%$ combined petty trading with farming. Local knowledge (84.50\%) largely contributed to agroforestry knowledge of the respondents. Educational qualifications of respondents were: FSLC (45.25\%), WAEC (48.25\%), OND/NCE $(6.00 \%)$, while $0.50 \%$ had HND/Degree. Types of agroforestry practices adopted by respondents, plant utility-form, mode of cultivation of agroforestry farms, problems affecting production of agroforestry, and source of nutrient in agroforestry farms in the study areas, all showed different significant results $(p=0.05)$. Further study is recommended to determine the appropriate plant compositions of individual plant species in the various agroforestry practices.
\end{abstract}

KEYWORDS: Agroforestry practices, ecological benefits, socio-economic livelihood, Abak LGA, Nigeria.

\section{INTRODUCTION}

One of the greatest problems facing Nigeria is the production of sufficient food to feed the increasing population. The need for more land to cultivate food has led to increased deforestation and consequently provoked degradative effects on the environment, leading to reduced productive capacity of land and diminishing crop yield. Indiscriminate fuelwood collection, illegal timber harvesting, and unregulated grazing have also aggravated land degradation in many parts of the tropics (Alabi et al., 2005; Gorse, 1985). Progressive trend of diminishing farm yield has resulted in food shortage, thereby accentuating rural poverty. Hence, current challenges for agricultural research in different regions of the world focus on how to provide farmers with appropriate technology so as to improve land productivity and enhance their living conditions. Agroforestry has proved to be a potent means of tackling the challenges of global food production on a sustainable basis (Udofia, 2007; ICRAF, 2000; Agbooala, 1980).

Agroforestry is the deliberate integration, in space or time, of woody perennials with herbaceous crops and or animals on the same land management unit. This can be simplified to be the practice of growing trees with agricultural crops and/or livestock on the same piece of land (Anderson et al., 1991). For agroforestry practices to be widely accepted and integrated into existing agricultural enterprises, farmers be sustainable. Many tree species are used in a variety of shapes, forms, and configurations to produce benefits as agroforestry components to adjacent crops or livestock. Trees provide many benefits including lumber and environmental services such as shade and wind protection for crops, livestock and buildings, erosion control, water and nutrient cycling, and supply wildlife food and habitat.

In Nigeria, agroforestry has gradually enhanced the socio-economic livelihood of rural people by boosting income earning potentials, human welfare, food and nutritional security as well as provision of fuelwood, fodder for animal consumption and employment (Mande, 2003). In addition, the ecological benefits include watershed protection, soil stabilization and improvement and carbon sequestration. Worldwide, it is generally accepted that agroforestry is a promising land use practice to maintain or increase agricultural productivity while preserving or improving fertility (Wein, 2003; Kang et al., 1990; MacDicken and Vergara, 1990; Leakey, 1996; Ingram, 1990). In recent years, increasing pressure on land in tropical countries has resulted in massive deforestation, with consequent erosion and reduction in soil fertility as well as serious shortages of fuelwood. Adedire (2003) reported that deforestation has adversely affected the environment. It has caused rapid run-off on watersheds, causing rivers to flood the site

S. I. Udofia, Department Of Forestry And Wildlife, University Of Uyo, Akwa lbom State, Nigeria.

P. W. Owoh, Department Of Forestry And Wildlife, University Of Uyo, Akwa Ibom State, Nigeria.

Y. K. Thomas, Department Of Forestry And Wildlife, University Of Uyo, Akwa Ibom State, Nigeria.

must be able to accomplish them safely, efficiently, and with tools already available on the farm. Agroforestry practices must be friendly to the farmer and land for it to rammes and vings many untoia miserıes to me rural masses. Other consequences of deforestation include shortage of construction poles and timber, fuelwood problems in some areas, shortage of fodder during the 
dry season, declining soil fertility leading to low crop yields and increased soil erosion. These consequences of deforestation have made agricultural scientists to realize that trees have a crucial role to play in tropical and temperate agriculture, and that they should not be confined to intensive plantations alone, but should be integrated with arable agriculture and livestock farms.

Agroforestry, a popular concept among agricultural, forestry and environmental scientists, can enhance the rural development needs in Africa. Its popularity stems from the increasing evidence that trees and shrubs can be arranged to significantly enhance, and guarantee the sustainability of agricultural systems. Agroforestry offers alternative approach to intensive agricultural development schemes that in the past have often resulted in decreased soil fertility and less of soil restoration potentials (ICRAF, 2000; Ingram, 1990; Nair, 1985). Essentially, agroforestry is the modification and/or adaptation of the fallow-based traditional farming systems in which the fallow phases are replaced through the incorporation of trees/shrubs on farmlands. The trees/shrubs not only play the role of fertility restoration, but also provide other tangible economic benefits which include provision of fuelwood for household energy consumption, restoration of water table to an absorbable level for crops, improvement of the microclimate effects of immediate and adjoining environment, provision of fodder, food for livestock and prevention of wind/water erosion as trees intercept the rain drop impact on the soil and reduction in the length of bush fallowing (Udofia, 2007; Azeez et al., 2005; Olujobi and Oke, 2005; ICRAF, 2000; Adesina, 1999; MacDicken and Vergara, 1990; Nair, 1985; Spears,1983).

An agroforestry practice denotes a specific land management unit and a specific arrangement, temporally and/or spatially, of component plants and animals. Azeez et al. (2005) stated that perception of farmers toward agroforestry practices varies from one agro-ecological zone to another, and they adopt specific agroforestry practices based on peculiar household needs. Unanaonwi and Bada (2004) noted that the customary right to land ownership in Ayepe and Ajibode communities in Osun and Oyo States, respectively hindered the active participation of women in agroforestry practices.

The choice of a suitable agroforestry practice in Nigeria is influenced by the location and specific nature of the various zones or regions as a number of factors such as different ecological zones limit the adoption of a single practice for the entire country (Mande, 2003). So far, only limited effort has been made in current research to show-case the success stories and the state of traditional agroforestry practices in rural communities of Nigeria (Kang and Wilson, 1987). It is essential that researches are geared toward understanding the existing farming practices, with a view to encourage better farming practices such as agroforestry in order to increase yield in the prevailing conditions. This study investigates into the agroforestry practices in Abak Local Government Area of Akwa Ibom State, Nigeria. The following null hypotheses were verified:

\section{Null Hypotheses}

$\mathrm{Ho}_{1}$ : There was no significant difference in the preference for agroforestry practices in Abak LGA of Akwa Ibom State, Nigeria.

$\mathrm{Ho}_{2}$ : There was no significant difference in the sources of nutrient for agroforestry farms in Abak LGA of Akwa Ibom State, Nigeria.

$\mathrm{Ho}_{3}$ : There were no significant problems in agroforestry production in Abak LGA of Akwa Ibom State, Nigeria.

$\mathrm{Ho}_{4}$ : There was no significant difference in the mode of cultivation of agroforestry farms in Abak LGA of Akwa Ibom State, Nigeria.

\section{METHODOLOGY}

Study area: Abak Local Government Area is located within latitude $11^{\circ} \mathrm{N}$ and longitude $7^{\circ} \mathrm{E}$, with a population 139,090 (FRN, 2007). The area is characterized with dense growth of vegetation. Climate of the area is characterized by rainy season (March to October) and dry season (November-February). Rainfall ranges from 2000-3000mm per annum. Temperatures are generally high all year round, ranging between $26^{\circ} \mathrm{C}$ and $28^{\circ} \mathrm{C}$. Relative humidity is commonly high and uniform. This gives rise to luxuriant vegetation all year round.

Data collection: Well-structured questionnaires, field observations and oral interview were used to collect data from randomly selected agroforestry farmers in each of the four clans (Abak, Otoro, Midim and Afahaobong) in Abak Local Government Area of Akwa Ibom State, Nigeria. In this study, agroforestry farmers are those who deliberately grow timber trees and agricultural crops and/or animals on a single piece of land for the purpose of increasing total yield and conserving the environment. One hundred (100) questionnaires were administered per clan, bringing to a total 400 questionnaires administered in the four clans (Table 1).

Table 1: Mode of selection of respondents (agroforesters) in Abak LGA, Akwa lbom State, Nigeria.

\begin{tabular}{|l|l|l|l|}
\hline Clan & No of agroforestry farmers identified & No selected & $\%$ sampling intensity \\
\hline Midim & 331 & 100 & 30.21 \\
\hline Abak & 325 & 100 & 30.77 \\
\hline Otoro & 329 & 100 & 30.40 \\
\hline Afaha Obong & 334 & 100 & 30.00 \\
\hline
\end{tabular}

Data analysis: Data were initially analyzed using descriptive statistical method of means of responses and percentages while ANOVA was later applied to verify the hypotheses. Fisher's-least significant difference (F-LSD) was used to separate treatment means according to the procedures of Steel and Torrie (1980). 


\section{RESULTS AND DISCUSSION}

Demographic information about the respondents.

Table 2 shows the demographic information about the respondents. Both males (67.25\%) and females (32 75\%) were involved in agroforestry practices. The low percentage of females could be due to the fact that questionnaires were distributed on household basis where males were primarily heads. Moreover, tradition allows male ownership of land in Akwa Ibom State of Nigeria. The higher percentage of males in the practice of agroforestry can provide additional labour to increase yield. Males are able to cover a large area of planting, weeding, harvesting during a short period of time. Females have less energy to work when compared to men and they are often busy with other family chores (Udofia, 2007).

In terms of occupation, $56.75 \%$ of respondents practised full-time farming, $23.25 \%$ were petty traders/farmers and $20.00 \%$ combined farming with civil service work (Table 2). The involvement of petty traders and civil servants indicates the motivation of the whole Abak Local Government Area population towards the production of agroforestry practices. This situation encourages the introduction and application of new technologies which will be easy with the civil servants and investment with the petty traders. In terms of marital status, Table 2 shows that $89.50 \%$ were married while $10.50 \%$ were single. Ages of respondents were $30-49$ $(81.75 \%)$ and above 50 years $18.25 \%$. These results express the high participation of young and energetic individuals in agroforestry practices. Unanaonwi and Bada (2004) found that people actively participating in agroforestry practices were in age brackets of 32-37 years. The lower proportion of older people involved in the practice might be as a result of physical weakness since energy is required in agroforestry operations because they are tedious. $84.50 \%$ of respondents had the knowledge of various agroforestry practices from local knowledge which, they obtained either through inheritance or several years of experience (Table 2). Formal education contributed to the knowledge of about $7.25 \%$ of the respondents. These were likely to be those who had OND/NCE or HND/degree. All the respondents (100\%) own agroforestry farms (Table 2).

Table 2: Demographic information about the respondents

\begin{tabular}{|l|l|l|}
\hline VARIABLE & FREQUENCY & PERCENTAGE (\%) \\
\hline Gender & 269 & \\
Male & 131 & 67.25 \\
Female & & 32.75 \\
\hline Status in the family & 248 & \\
Father & 152 & 62.00 \\
Mother & & 38.00 \\
\hline Occupation & 227 & \\
Full-time farming & 80 & 56.75 \\
Civil service/farming & 93 & 20.00 \\
Petty trading/farming & & 23.25 \\
\hline Marital status & 42 & \\
Single & 358 & 10.50 \\
Married & 327 & 89.50 \\
\hline Age (Years) & 73 & \\
30-49 & & 81.75 \\
$>50$ & 181 & 18.25 \\
\hline Education & 193 & 45.25 \\
FSLC & 24 & 48.25 \\
WAEC & 2 & 6.00 \\
OND/NCE & & 0.50 \\
HND/Degree & 328 & \\
\hline Source of agroforestry knowledge & 29 & 84.50 \\
Local knowledge & 33 & 8.25 \\
Formal education & & \\
Extension agents & 400 & 100.00 \\
\hline Ownership of agroforestry farm & 0.0 \\
Yes & & \\
No & & \\
\hline
\end{tabular}

\section{Various agroforestry practices adopted by} respondents.

Table 3 shows the agroforestry practices adopted by respondents in Abak Local Government Area of Akwa Ibom State. There were significant differences between the agroforestry practices adopted in Abak local government area of Akwa lbom State (Table 9). Homegarden had the highest significant $(p=0.05)$ level implying that it is the most widespread agroforestry practice in Abak Local Government Area. This result agrees with Udofia (2007) who found that
12

Akwa lbom State. Life fence, boundary planting, scattered trees and shifting cultivation had similar significant levels $(p=0.05)$, whereas orchards and fodder plants had statistically similar respondents. Snailery and rabbit keeping gave significantly the least responses.

The result explains that there were at least nine different agroforestry practices adopted by farmers in Abak Local Government Area. This information is very relevant to the government who may wish to encourage production of food and other agroforestry products in 
Akwa Ibom State. Any intervention on improving food production in Abak Local Government Area should concentrate more in improving production in homegardens because all the agroforestry farmers have homegardens. The preference of homegardens may be due to the fact that it is near their homes, a situation that could facilitate effective management. Homegardens have the potential to supply food, vegetables, spices and even medicinal plants within close proximity (Udofia, 2007). A diminishing interest in shifting cultivation was observed in the study areas. This may be a consequence of decreasing per capita land holding in the study areas coupled with increasing population.

Table 3: Agroforestry practices adopted by respondents in Abak LGA of Akwa Ibom State,
\begin{tabular}{|l|c|c|c|c|c|c|}
\hline $\begin{array}{l}\text { Agroforestry } \\
\text { practices }\end{array}$ & Midim & Abak & Otoro & Afaha- Obong & Total & Mean \\
\hline Homegarden & 100 & 96 & 100 & 100 & 396 & 99 \\
\hline Shifting cultivation & 24 & 56 & 59 & 69 & 207 & 51.75 \\
\hline Scattered trees & 61 & 43 & 71 & 59 & 234 & 58.5 \\
\hline Orchard & 21 & 39 & 53 & 42 & 155 & 38.75 \\
\hline Boundary trees & 86 & 67 & 89 & 37 & 279 & 69.75 \\
\hline Life fence & 76 & 46 & 61 & 69 & 252 & 63 \\
\hline Fodder trees & 32 & 11 & 24 & 19 & 86 & 31.5 \\
\hline Snailery & 3 & 1 & 8 & 4 & 16 & 4 \\
\hline Rabbit keeping & 1 & 0 & 2 & 2 & 5 & 1.25 \\
\hline F-LSD & & & & & & 18.45 \\
\hline
\end{tabular}

$$
\text { F-LSD (0.05) }
$$

\section{Plant utility-forms preferred by respondents.}

Table 4 explains the preference of respondents for different plant utility-forms. There were significant differences in preference for utility-forms. It is probable that vegetables, fruit trees, oil palm, raffia palm and root crops were utilized more frequently because they had significantly higher results in their utility-form than lesser utilized plants such as spices, fodder and medicinal plants, which had similar statistical values. Timber trees had the least significant value among the plant utility forms in agroforestry farms in Abak Local Government Area of Akwa lbom State. These results explain that agroforestry farmers in the study areas placed more interest in the cultivation of plants in the order of vegetables $>$ fruit trees $>$ oil plant/raffia palm $>$ root crops $>$ spices $>$ fodder trees $>$ timber tree (See Table 7). Udofia (2007) found that homegarden owners preferred to plant food and vegetables in their farms.
Agroforestry farmers prefer to plant vegetables and fruit trees because, apart from their food value, they are major sources of household income to families. Farmers also rely on oil palm, palm wine from raffia palm and root crops such as cassava, cocoyam and yam as important food and income sources. The low interest of farmers in the cultivation of timber trees could be traceable to small farm holdings and the fact that some timber trees do not produce any food and income within one year. Respondent also complained of the long period they have to wait before harvesting a timber tree, whereas what they needed on daily basis were food and small income for family up-keeps. This result stresses the need to educate farmers on the importance of multi-purpose trees species which can supply food as well as timber, in addition to serving as fodder for animals.

Table 4: Preference of respondents for plant utility-forms.

\begin{tabular}{|l|c|c|c|c|c|c|}
\hline Utility forms & Midim & Abak & Otoro & Afaha-Obong & Total & Mean \\
\hline Timber trees & 14 & 6 & 11 & 18 & 49 & 12.25 \\
\hline Fruit trees & 100 & 98 & 100 & 96 & 394 & 98.5 \\
\hline Vegetable & 100 & 100 & 100 & 98 & 398 & 99.5 \\
\hline Spices & 78 & 91 & 88 & 79 & 336 & 84 \\
\hline Root crops & 100 & 68 & 99 & 98 & 355 & 88.75 \\
\hline Fodder trees & 26 & 11 & 56 & 38 & 131 & 32.75 \\
\hline Medicinal plant & 16 & 41 & 21 & 33 & 111 & 27.75 \\
\hline $\begin{array}{l}\text { Oil palm and wine } \\
\text { palm }\end{array}$ & 98 & 79 & 92 & 100 & 369 & 92.25 \\
\hline F-LSD & & & & & & $\mathbf{1 2 . 6 2}$ \\
\hline
\end{tabular}

F-LSD (0.05)

STUDY ON AGROFORESTRY PRACTICES IN ABAK Mode of cultivation of agroforestry farm by respondents in the study area.

Table 5 shows the mode of cropping by respondents in the study areas. Annual cropping had the highest statistical significant at $0=0.05$, followed by agroforestry farmers who cultivated their farms twice a year (Table 9). Shifting cultivators did not show statistical significance. Annual and biannual cultivators could be owners of homegardens. The result is consistent with Udofia (2007) who found that all households in Akwa Ibom State practised homegardening at various levels and dimensions. Homegardens provide many different foods, environmental services and. often protect under 
utilized species which are not popular but which have immediate market value and relevance in the livelihood of rural people. Homegardens have equally been employed in the production of animal-based protein to households in both rural and urban areas (Udofia, 2007). Shifting cultivators showed the lowest statistical year. Shifting cultivation involves the rotation of fields rather than crops. Population pressure has been reported as one of the major factors affecting the continued relevance of shifting cultivation as an agroforestry practice (Whitmore, 1990).

Table 5: Mode of cultivation of agroforestry farm by respondents in the study areas.

\begin{tabular}{|l|l|l|l|l|l|l|}
\hline Tenure & Midim & Abak & Otoro & Afaha-Obong & Total & Mean \\
\hline Annually & 98 & 89 & 100 & 99 & 386 & 96.5 \\
\hline Biannually & 76 & 69 & 81 & 68 & 294 & 73.5 \\
\hline Shifting cultivation & 44 & 21 & 39 & 23 & 127 & 31.75 \\
\hline F-LSD & & & & & & $\mathbf{8 . 3 6}$ \\
\hline
\end{tabular}

$$
\text { F-LSD (0.05) }
$$

\section{Problems affecting agroforestry production in the study areas.}

Problems that affect agroforestry production in the study areas are presented in Table 6 . There were significant differences (Table 9) between the various problems affecting the practice of agroforestry in Abak Local Government Area at $p=0.05$. Lack of money was the major significant factor at $0=0.05$, followed by the similarly significant lack of improved planting stocks and inadequate land. High cost of labour and the changing climatic conditions had similar significant effects, whereas diminishing soil nutrient and pests and diseases had the least statistical values $(0=0.05)$. Respondents in all the study areas complained that lack of money hindered their ability to procure additional land, inputs and equally pay for the increasing labour cost. Lack of money in any project is capable of jeopardizing the progress and achievement of set goals.

Lack of improved planting stocks was a serious setback for the agroforestry farmers. Local breeds and stocks might not yield to the satisfaction of the farmers who, perhaps were expected to feed members of their families and also have surplus for sale to generate income. The combined effect of inadequate funds, inadequate land and diminishing soil nutrients are capable of drastically reducing production of agroforestry project. However, diminishing soil nutrients did not pose a serious problem to farmers in the study areas. Pests and diseases did not constitute an important hindrance to production. This could be so because of the many plant mixtures in most of the agroforestry practices which have been adopted by farmers in Abak Local Government Area.

Table 6: Problems faced by agroforestry farmers in Abak local Government Area

\begin{tabular}{|l|c|c|c|c|c|c|}
\hline Problems & Midim & Abak & Otoro & Afaha-Obong & Total & Mean \\
\hline Inadequate land & 69 & 73 & 52 & 63 & 257 & 64.25 \\
\hline Lack of money & 61 & 79 & 81 & 76 & 297 & 74.25 \\
\hline Lack of improved stock & 66 & 89 & 91 & 77 & 323 & 80.75 \\
\hline Diminishing soil nutrient & 18 & 21 & 17 & 30 & 86 & 21.5 \\
\hline Change in weather condition & 26 & 33 & 18 & 31 & 108 & 27 \\
\hline High cost of labour & 39 & 41 & 26 & 13 & 119 & 29.75 \\
\hline Pests/diseases & 19 & 13 & 7 & 12 & 51 & 12.75 \\
\hline F-LSD & & & & & & 13.21 \\
\hline
\end{tabular}

$$
\text { F-LSD (0.05) }
$$

\begin{tabular}{|c|c|c|c|c|c|c|}
\hline Homegarden & $\begin{array}{l}\text { Shifting } \\
\text { cultivation }\end{array}$ & Orchard & $\begin{array}{l}\text { Scattered } \\
\text { trees on } \\
\text { farms }\end{array}$ & $\begin{array}{c}\text { Boundary } \\
\text { trees }\end{array}$ & Life fence & Fodder trees \\
\hline $\begin{array}{l}\text { Vernonia } \\
\text { amygdaling }\end{array}$ & $\begin{array}{l}\text { Manihot } \\
\text { esculenta }\end{array}$ & $\begin{array}{l}\text { Gambeya } \\
\text { albida }\end{array}$ & Eucalyptus sp & $\begin{array}{l}\text { Newbouldia } \\
\text { laevis }\end{array}$ & $\begin{array}{l}\text { Spondias } \\
\text { mombin }\end{array}$ & Gliricidia sepium \\
\hline $\begin{array}{l}\text { Telfaria } \\
\text { occidentalis }\end{array}$ & $\begin{array}{l}\text { Calliandra } \\
\text { calothyrsus }\end{array}$ & Carica papaya & Albizzia $s p$ & $\begin{array}{l}\text { Gmelina } \\
\text { arborea }\end{array}$ & $\begin{array}{l}\text { Bambusa } \\
\text { vulgaris }\end{array}$ & $\begin{array}{l}\text { Leucaena } \\
\text { leucocephala }\end{array}$ \\
\hline Discorea spp & $\begin{array}{l}\text { Sesbania } \\
\text { grandiflora }\end{array}$ & $\begin{array}{l}\text { Ananas } \\
\text { comosus }\end{array}$ & $\begin{array}{l}\text { Masanga } \\
\text { cecropoides }\end{array}$ & $\begin{array}{l}\text { Tectona } \\
\text { grandis }\end{array}$ & ficus $s p$ & $\begin{array}{l}\text { Pithecellobium } \\
\text { dulca }\end{array}$ \\
\hline Matihot & Alhornea & Dacryodes & Raphia & JARZEdiAachtdW & WEACiAND & - SestBdaMAS \\
\hline esculenta & cordifolia & edulis & vinifera & indica & albida & grandiflora \\
\hline $\begin{array}{l}\text { Musa } \\
\text { paradisiaca }\end{array}$ & $\begin{array}{l}\text { Leucaena } \\
\text { leucocephala }\end{array}$ & $\begin{array}{l}\text { Persea } \\
\text { americana }\end{array}$ & $\begin{array}{l}\text { Elaeis } \\
\text { guineensis }\end{array}$ & $\begin{array}{l}\text { Gnetum } \\
\text { Africanum }\end{array}$ & $\begin{array}{l}\text { Prosopis } \\
\text { juliflora }\end{array}$ & $\begin{array}{l}\text { Artocarpus } \\
\text { heterophylus }\end{array}$ \\
\hline Musa sapientum & Alstonia boonei & $\begin{array}{l}\text { Psidium } \\
\text { guajaua }\end{array}$ & $\begin{array}{l}\text { Acacia } \\
\text { auriculiomis }\end{array}$ & $\begin{array}{l}\text { Alstonia } \\
\text { boonei }\end{array}$ & & \\
\hline $\begin{array}{l}\text { Cymbopogon } \\
\text { citratus }\end{array}$ & $\begin{array}{l}\text { Artocarpus } \\
\text { commounis }\end{array}$ & $\begin{array}{l}\text { Prunus } \\
\text { armentacca }\end{array}$ & $\begin{array}{l}\text { Gnetum } \\
\text { africanum }\end{array}$ & $\begin{array}{l}\text { Cola } \\
\text { acuminate }\end{array}$ & & \\
\hline Zea mays & Ceiba pentandra & Cocos nucifera & Cassia sp & & & \\
\hline
\end{tabular}

Table 7: Plant species found in agroforestry plots in Abak local government area. 


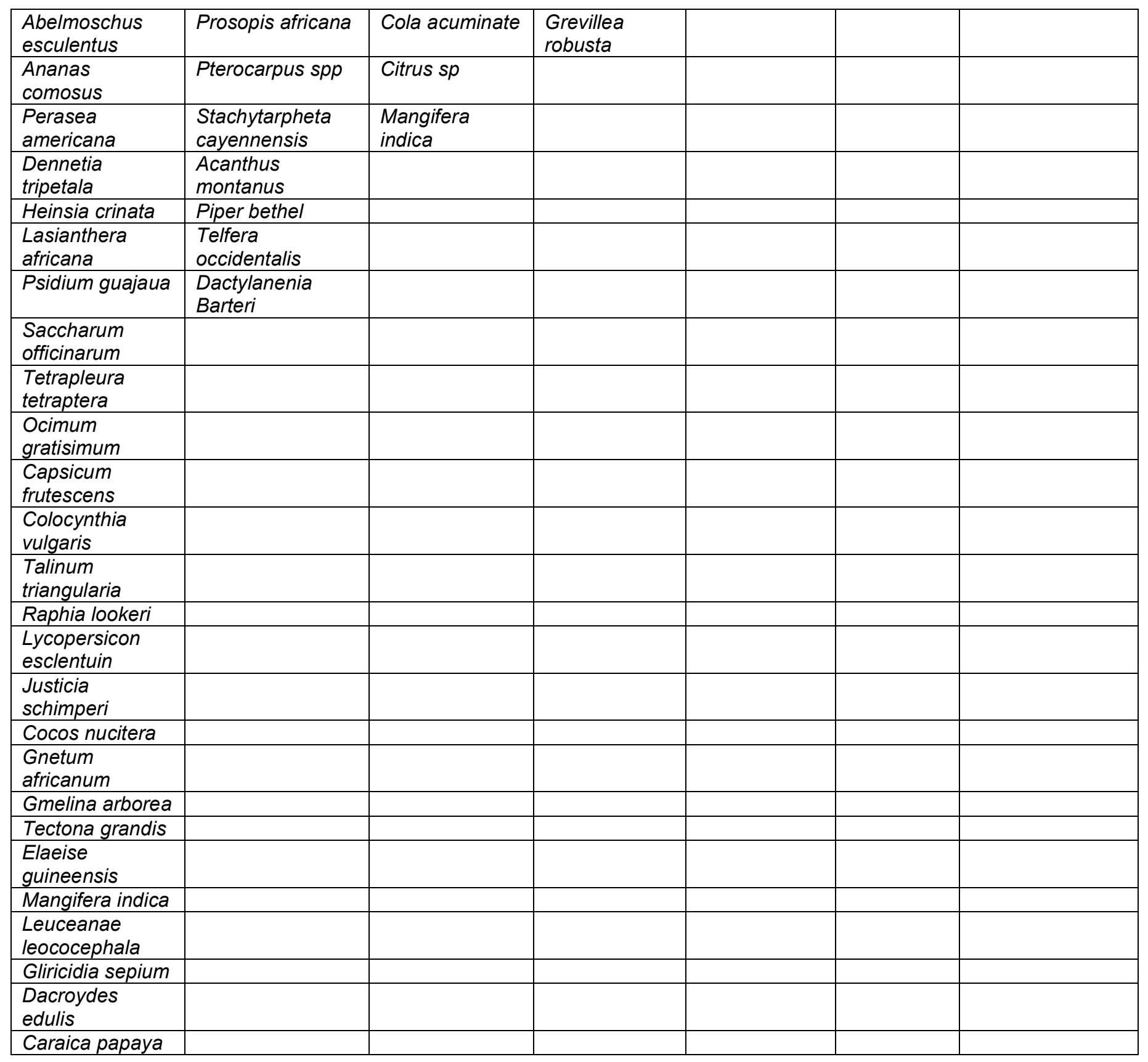

Sources of nutrient for agroforestry farms as reported by respondents

Table 8 shows the sources of nutrient to respondents in agroforestry farms. There was significant difference between the two sources of nutrient for application at the various agroforestry farms in the study area (Table 8). Organic fertilizer gave significantly higher value $(p=0.05)$ while inorganic fertilizer did not have significant impact (Table 9). This means that most of the respondents use organic fertilizer such as household refuse, animal waste sand green manure as their main sources of nutrient in their farms. The result corroborates that of Udofia (2007), who found that agroforestry farmers generally depended on organic

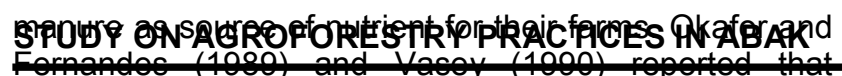

household waste, crop residues and livestock waste were the dominant sources of plant nutrients in agroforestry farms in southeastern Nigeria, West Java and Papua New Guinea. Oral interview with the respondents indicated that inorganic fertilizers were very expensive and could not be afforded by them. Some of them opined that even if they were able to purchase the item, they did not know how to apply the inorganic fertilizer to achieve desired increase in yield. The aim of agroforestry is to encourage low input-high output farming methods which discourage the use of chemical fertilizers.

Table 8: Source of nutrient in agroforestry farms in the study area

\begin{tabular}{|l|l|l|l|l|l|l|}
\hline Input & Midim & Abak & Otoro & Afaha-Obong & Total & Mean \\
\hline Chemical fertilizer & 1 & 16 & 9 & 39 & 65 & 16.25 \\
\hline Organic manure & 99 & 84 & 91 & 61 & 335 & 83.75 \\
\hline F-LSD & & & & & & $\mathbf{5 2 . 0 2}$ \\
\hline
\end{tabular}


TABLE 9: SUMMARY OF DATA ANALYSIS.

\begin{tabular}{|l|c|c|c|}
\hline \multicolumn{1}{|c|}{ NULL HYPOTHESES } & F-CAL & F-TAB & REMARK \\
\hline $\begin{array}{l}\mathrm{Ho}_{1}: \quad \text { There was no significant difference in the preference } \\
\text { for agroforestry practices in Abak LGA of Akwa Ibom State, } \\
\text { Nigeria. }\end{array}$ & 25.71 & 2.36 & SIGNIFICANT \\
\hline $\begin{array}{l}\mathrm{Ho}_{2}: \quad \text { There was no significant difference in the sources of } \\
\text { nutrient for agroforestry farms in Abak LGA of Akwa Ibom } \\
\text { State, Nigeria. }\end{array}$ & 17.03 & 9.28 & SIGNIFICANT \\
\hline $\begin{array}{l}\mathrm{Ho}_{3}: \text { Production problem did not constitute There was no } \\
\text { significant problem in agroforestry production in Abak LGA of } \\
\text { Akwa Ibom State, Nigeria. }\end{array}$ & 39.09 & 2.66 & SIGNIFICANT \\
\hline $\begin{array}{l}\mathrm{Ho} \text { : There was no significant difference in the mode } \\
\text { cultivation of agroforestry farms in Abak LGA of Akwa lbom } \\
\text { State, Nigeria. }\end{array}$ & 4.97 & 4.76 & SIGNIFICANT \\
\hline
\end{tabular}

\section{RECOMMENDATIONS}

Further studies are needed with a view to improving the production potentials of the preferred agroforestry practices in Abak LGA of Akwa Ibom State, Nigeria. Availability of improved planting stocks to farmers in the study areas could enhance total yield. Efforts should be made to popularize multipurpose tree species among the farmers. Since local knowledge was largely used by agroforestry farmers at all the study areas, it will be sensible to investigate how such local knowledge could be strengthened for better performances.

\section{CONCLUSION}

The study revealed that agroforestry practices such as homegarden, shifting cultivation, scattered trees, orchard, boundary trees, life fence, fodder trees, snailery and rabbit keeping were common in the study areas, and homegarden was the most popular. Agroforestry practices were generally dependent on indigenous knowledge. It is important to strengthen the capacity of the people to utilize their existing local knowledge of agroforestry practices through technical support in the form of extension services.

\section{REFERENCES}

Adedire, M. O., 2003. Agroforestry for rural prosperity. Breaking new grounds in Ogun State: Employment Generation under the Administration of Otumba Gbenga Daniel. An Ogun State Agricultural Employment Generation Publication. Abeokuta, Nigeria. 79pp.

Adesina, F. A., 1999. Potential of agroforestry techniques in mitigating $\mathrm{Co}_{2}$ emission in Nigeria some preliminary estimates. Global Ecology and Biogeography. 8:163-173.

Agbooala, A. A., 1980. Effect of different cropping systems on crop yield and soil fertility management in humid zone. FAO Bulletin. 43:87-105.

Alabi, O., Adebayo, O., Olumiyiwa, A.A., Apene, E., Balogun, O. S. and Onwuegbunam, N., 2005. The Role of Agroforestry Technologies in Agricultural Development in Nigeria. Proceedings of the $30^{\text {th }}$ Annual Conference of Forestry Association of Nigeria, 7th $-11^{\text {th }}$ November, 2005, Kaduna, Kaduna State. pp. 232-236.

Anderson, S. T. G. Bidwell, and Romann. L., 1991. Introduction to Agroforestry alternatives. Oklahoma State Univ. Ext. Serv., Still-water, OK. UK. pp. 110-122.

Azeez, L.O., Labode P., Amussa T. O. and Adebisi L.A., 2005. Assessment of agroforestry practice as land use option in Atisbo Local Government Area of Oyo State. Proceedings of the 30th Annual Conference of Forestry Association of Nigeria, $7^{\text {th }}-11^{\text {th }}$ November, 2005, Kaduna, Kaduna State, Nigeria. pp 119-135.

Food and Agriculture Organization (FAO)., 1992. Forest, Trees and Food. FAO of the United Nations. Rome. 26p.

Federal Republic of Nigeria (FRN)., 2007. Official Gazette No. 24, Federal Government Printer, Lagos, Nigeria. 180p.

Gorse, J., 1985. Fuelwood and domestic energy: The Fuelwood crisis in tropical West Africa World Bank Washington D.C. 52p.

Ingram, J., 1990. The role of trees in maintaining and improving soil productivity: A review of the literature. In: Prinsley, R.T. (ed.) Agroforestry for Sustainable Production. Commonwealth Science Council, London. pp. 243-304.

ICRAF (International Center for Research in Agroforestry)., 2000. Path to Prosperity through Agroforestry. ICRAF's Corporate Strategy 20012010. ICRAF, Nairobi, Kenya. 43p. 
Kang, B. T., Wilson, G. F., 1987. The development of alley cropping as a promising agroforestry technology. In: Steppler, H.A. Nair, P.K.R. (eds.) Agroforestry: A Decade of Development. International Council for Research in Agroforestry, Nairobi, Kenya. pp. 227-244.

Kang, B. T., Wilson, G. F., and Mulongoy, K., 1990. Alley cropping: Trees as sources of green manure and mulch in the tropics. In: J.M. LopexReal (ed.) The Role of Microorganisms in a Sustainable Agriculture. University of London, Academic Publishers, UK. pp. 156-166.

Leakey, R., 1996. Definition of agroforestry revisited. Agroforestry Today. 8 (1):5-7.

MacDicken, K. G. and Vergara, N. T., 1990. Agroforestry: Classification and Management. John Wiley and Sons. New York. pp 56-69.

Mande, M., 2003. Agroforestry: A tool for accelerated socio- economic improvement of rural livelihood. Department of Forest Resources Management, Faculty of Agriculture and Forestry University of Ibadan, Nigeria. pp 1-17.

Nair, P.K.R., 1985. Classification of Agroforestry systems. Working Paper No. 28. ICRAF, Nairobi, Kenya, 51p.

Okafor, J. C. and Fernandes, E. C. M., 1989. The compound farms of southeast Nigeria: $A$ predominant agroforestry homegarden system with crops and small livestock. Agroforestry Systems. 5: 153-168.

Olujobi, O. J. and Oke, D. O., 2005. Assessment of Existing Agroforestry Practices in Ondo State, Nigeria. Proceedings of 30th Annual Conference of Forestry Association of Nigeria, 7th- $11^{\text {th }}$ November, 2005, Kaduna, Kaduna State. pp 110-118.

Spears, J. S., 1983. Replenishing the World's Forests, tropical reforestation: An achievable goal? Commonwealth Forestry Review. 62(3): 202217.

Steel, P. G. O. and Torrie, J. H., 1980. Principles and Procedures of statistics: A biometric approach. Second Edition, Mc-Graw Hill Book Co., New York, USA.

Udofia, S. I., 2007. Status of Homegardens in Akwa Ibom State. Unpublished Ph.D Dissertation, Michael Okpara University of Agriculture, Umudike, Abia State, Nigeria. pp. 25-90.

Unanaonwi, O. E. and Bada, S.O., 2004. Adoption of Agroforestry Systems in Ayepe and Ajibode Communities of Osun and Oyo State, Nigeria. Nigeria Journal of Forestry, 34(2): 118-124.

Vasey, D. E., 1990. On estimating the net social and economics of urban homegardens. In Landauer, K. and Brazil, M. (eds.) Tropical Homegardens. United Nations University Press, Tokyo, Japan. pp. 203-213.

Wein, A.M., 2003. Effect of land-use intensity in tropical agroforestry systems on coffee flower-visiting and trap nesting. Conservation Biology, 16:1003-1014.

Whitmore J.C., 1990. An Introduction to Tropical Rain forests. Oxford University Press Inc., New York, USA, pp 133-134. 
